\title{
Stream acidification and base cation losses with grassland afforestation
}

\author{
Kathleen A. Farley, ${ }^{1}$ Gervasio Piñeiro, ${ }^{2,3}$ Sheila M. Palmer, ${ }^{4}$ Esteban G. Jobbágy, ${ }^{3,5,6}$ \\ and Robert B. Jackson ${ }^{3}$ \\ Received 14 November 2007; revised 14 May 2008; accepted 3 June 2007; published 9 September 2008.
}

[1] Afforestation of natural grasslands with fast-growing pine and eucalyptus species is increasing globally, but little is known about its effect on ecosystems and watersheds and, ultimately, the quality of water resources. To investigate the biogeochemical and hydrological consequences of this land use change, we sampled stream water in paired watersheds in Uruguay and Argentina. In watersheds planted with pine, we found no change in stream $\mathrm{pH}$ following afforestation, while in watersheds planted with eucalyptus, $\mathrm{pH}$ was 0.7 units lower on average than in streams draining grasslands. To further investigate the mechanism behind the decrease in $\mathrm{pH}$, we sampled soils and streams of eucalypt catchments in Uruguay and analyzed exchangeable base cation concentrations, alkalinity, and dissolved inorganic carbon (DIC). At these sites, $\mathrm{Ca}, \mathrm{Mg}$, and $\mathrm{Na}$ concentrations were $>30 \%$ lower in afforested soils than in grassland soils, and $\mathrm{pH}$ was significantly lower below $10 \mathrm{~cm}$ depth. Stream measurements taken over three years illustrate that these soil changes were also manifested in stream water chemistry. In the eucalypt watersheds, base cation concentrations were $>40 \%$ lower, and alkalinity and DIC were halved in stream water. A test with data from additional sites where both pines and eucalypts were planted nearby showed that eucalyptus has a stronger acidifying effect than pine. Overall, our data suggest that repeated harvesting cycles at some locations could negatively impact the soil store of base cations and reduce downstream water quality. Our results can be used to help minimize negative impacts of this land use and to inform policy in this and other regions targeted for plantation forestry.

Citation: Farley, K. A., G. Piñeiro, S. M. Palmer, E. G. Jobbágy, and R. B. Jackson (2008), Stream acidification and base cation losses with grassland afforestation, Water Resour. Res., 44, W00A03, doi:10.1029/2007WR006659.

\section{Introduction}

[2] Attention to the importance of natural ecosystems in provisioning of water has increased at the same time that land use change, which can compromise this ecosystem service, continues at an accelerated rate [Millennium Ecosystem Assessment, 2005; Scanlon et al., 2007; Mark and Dickinson, 2008]. Increasingly, research on biophysical responses to land use change has revealed a variety of trade-offs that may occur between increased production of goods needed by human populations and loss or impairment of ecosystem services [Jackson et al., 2001; Foley et al., 2005]. In order to fully assess the trade-offs associated with land use change, quantitative data on ecosystem responses to land use are needed [DeFries et al., 2004]. In the case of conversion

\footnotetext{
${ }^{1}$ Department of Geography, San Diego State University, San Diego, California, USA.

${ }^{2}$ Facultad de Agronomía, Universidad de Buenos Aires, Buenos Aires, Argentina.

${ }^{3}$ Department of Biology and Nicholas School of the Environment and Earth Sciences, Duke University, Durham, North Carolina, USA.

${ }^{4}$ School of Geography, University of Leeds, West Yorkshire, UK.

${ }^{5}$ Grupo de Estudios Ambientales, IMASL, Universidad Nacional de San Luis, San Luis, Argentina.

${ }^{6}$ CONICET, San Luis, Argentina.
}

Copyright 2008 by the American Geophysical Union. 0043-1397/08/2007WR006659\$09.00 from natural to agricultural systems, existing research has demonstrated large impacts on water resources through changes in water quantity and quality, via mobilization of salts, salinization, and leaching of fertilizers [e.g., Scanlon et al., 2007]. While conversion of natural ecosystems to tree plantations is a land use change that has generally received less attention, it is increasingly seen in the context of a tradeoff that can increase production of timber and other goods but reduce water quantity and, with a more incomplete understanding, water quality [Calder, 1986; Dye, 1996; Vertessy, 1999; Farley et al., 2005; Jackson et al., 2005; Farley, 2007; van Dijk and Keenan, 2007]. Land use impacts on water quality, as well as water quantity, need consideration in order to manage water resources sustainably [Scanlon et al., 2007]. Like impacts on water quantity, effects on water quality have relevance both at the site where land use change occurs and downstream, crossing scales (from stand to watershed) and habitats (from terrestrial to aquatic).

[3] Streams link terrestrial and aquatic systems by carrying dissolved nutrients from watersheds to rivers, lakes, and estuaries. Although streams process materials in their own right, they also carry the imprint of land use within their watershed, including differences in stream solute concentrations, nutrient fluxes, and acidity [Howarth et al., 1996; Goodale et al., 2000; Ometo et al., 2000; Biggs et al., 2004; 
Meynendonckx et al., 2006]. Changes in land use and land cover, such as afforestation, alter the type and solubility of litter inputs, the characteristics of soil organic matter, and the size of soil nutrient stocks on land and downstream, including the water that ultimately reaches lakes, estuaries, and oceans [Lewis et al., 1999; Jackson et al., 2000; Hood et al., 2003]. At the same time, changes in nutrient retention or mobilization alter nutrient movement through hydrologic pathways and can have long-term effects on ecosystem productivity, carbon storage, and freshwater communities [Bernhardt and Likens, 2002; Perakis and Hedin, 2002; Strauss and Lamberti, 2002; Sobczak et al., 2003].

[4] Afforestation is becoming increasingly prevalent, with global plantation area increasing by $>40 \%$ between 1990 and 2005, when it reached 139.1 million ha [van Dijk and Keenan, 2007]. Many changes in ecosystem processes have been associated with this land use change, including the acidification of some soils and reductions in soil cation concentrations under plantations [Brand et al., 1986; Binkley et al., 1989; Rhoades and Binkley, 1996; Alfredsson et al., 1998; Jobbágy and Jackson, 2003; Farley and Kelly, 2004; Jobbágy and Jackson, 2007]. In a global synthesis, Jackson et al. [2005] found that plantation soils became more acidic than the previous land cover in 98 of 114 cases evaluated, with a median decrease of $0.3 \mathrm{pH}$ units and decreases of $0.5-1.6$ units in $25 \%$ of the cases.

[5] Acidification of stream water also has been documented following plantation establishment in acidic headwater catchments, yet little is known about the effect of afforestation on stream chemistry in areas of low acid deposition [Harriman and Morrison, 1982; Cosby et al., 1990; Jenkins et al., 1990; Clenaghan et al., 1998]. Further, the link between the response in streams and that in soils is poorly understood. Some authors have suggested that the acidifying effect of plantations on streams may be less than the effect on soils [Jenkins et al., 1990]. Yet research in forested and nonforested catchments indicates that changes in stream chemistry tend to reflect fine-scale changes in soil chemical properties [Biggs et al., 2002; Palmer et al., 2004; Billett et al., 2006]. In contrast to studies of acid deposition, the link between biogeochemical changes in soils and streams as a consequence of afforestation has rarely been studied and is poorly understood [Waters and Jenkins, 1992].

[6] Both hydrological and biogeochemical mechanisms likely alter stream chemical composition as a result of afforestation. In the first case, higher stream solute concentrations would accompany afforestation if increased evapotranspiration reduced streamflow [Zhang et al., 2001; Engel et al., 2005; Farley et al., 2005; Jackson et al., 2005]. This purely hydrologic mechanism would increase solute concentrations in proportion to the amount of streamflow reduction. In the second case, biogeochemical mechanisms with afforestation of grasslands could either retain or mobilize nutrients, leading to lower or higher stream solute concentrations, respectively. These mechanisms include cation sequestration in tree biomass (retention), leaching of organic acids from the tree canopy and litter layer (mobilization), and addition of carbonic acid with higher rates of soil respiration (mobilization), and would reflect the redistribution of nutrients among plant, soil, and water pools. In nature, both hydrological and biogeochemical mechanisms likely interact to control changes in stream water chemistry. For example, enhanced mobilization of solutes potentially could be amplified by streamflow reduction.

[7] Changes in stream biogeochemistry following afforestation can be associated with changes in both water quality and site productivity. Acidification, for instance, can have detrimental impacts on aquatic species [Allott et al., 1993; Kelly-Quinn et al., 1996; Friberg et al., 1998]. If cations retained in tree biomass are harvested and exported from the system, persistent soil acidity and long-term nutrient loss may occur [Alfredsson et al., 1998]. These effects are particularly relevant since afforestation with pines and eucalypts is occurring on some highly productive grasslands, such as those in Argentina and Uruguay. Both countries are likely to be important fronts for afforestation in the coming decades; Argentina is estimated to have $20,000,000$ ha that have been designated as appropriate for forestry, only $4 \%$ of which has been afforested, while Uruguay has 3,600,000 ha, of which less than $10 \%$ has been afforested (M. Angel, South American forestry industry, World Forest Institute, Portland, Oregon, available at http:// www.cintrafor.org/OUTREACH_TAB/presentations/Mario\%20Angel.pdf). Between $1990^{-}$and 2000, expansion of tree plantations was the dominant land use change in the agricultural census, with plantations occupying more than $35 \%$ of the land area in some counties [Paruelo et al., 2006].

[8] In this analysis, we studied 13 sites in Lavalleja Province, Uruguay and Córdoba Province, Argentina and 1 additional site in Tacuarembó, Uruguay where plantations were established on and adjacent to native grasslands. Our goals were as follows.

[9] 1. Analyze the effect of afforestation on stream water $\mathrm{pH}$ in two regions with different climatic and soil/parent material characteristics, one afforested with pines and the other with eucalypts.

[10] 2. Identify hydrological versus biogeochemical effects of afforestation with eucalyptus and evaluate to what extent changes in soil properties are mirrored in stream water characteristics. To accomplish this goal we used more detailed local studies in one region, including sites with the same climate, soil/parent material, and tree species.

[11] 3. Investigate the effects of plantation species on stream water $\mathrm{pH}$ at a single site (with identical soil/parent material type) planted with both pines and eucalypts.

[12] Our approach allowed us to isolate the effects of afforestation on soil and stream chemistry, as well as to help develop a general framework for predicting the consequences of afforestation in other regions targeted for plantation forestry.

\section{Methods}

\subsection{Study Sites}

[13] We examined the conversion of grasslands to plantations at 13 sites in Argentina and Uruguay. In each country, we established pairs of grassland-plantation watersheds, including 5 pairs in Córdoba, Argentina planted with pine and 8 pairs in Lavalleja, Uruguay planted with eucalyptus. For our regional analysis, we sampled stream $\mathrm{pH}$ seven times between 2004 and 2006 at all 13 sites. In a more detailed analysis performed at the 8 sites in Lavalleja, 


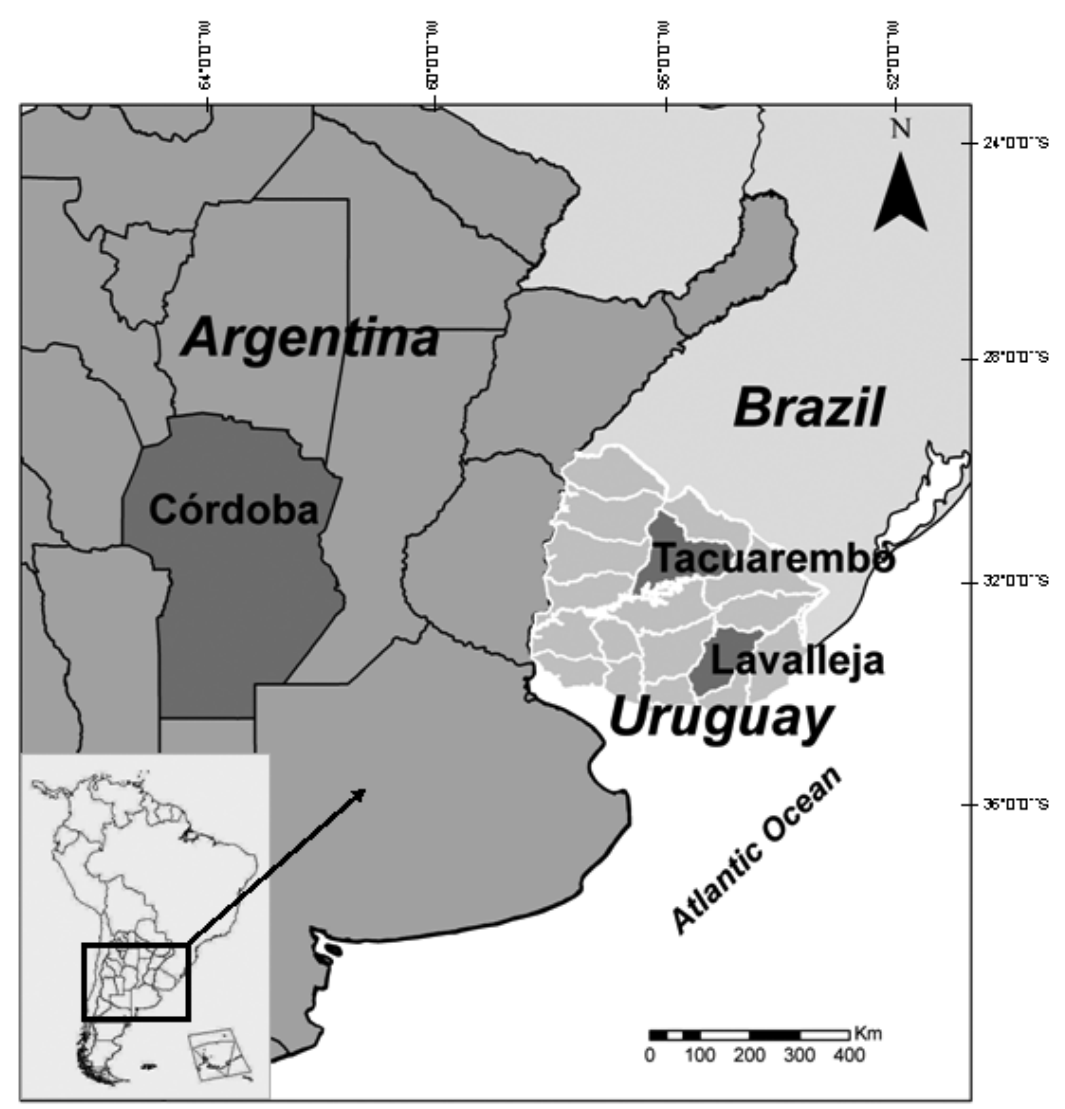

Figure 1. Map of study areas, including regions of sampling in Córdoba, Argentina, and Lavalleja and Tacuarembó, Uruguay.

Uruguay we also analyzed base cations, alkalinity and dissolved inorganic carbon (DIC) in stream water and sampled soils at each site. Finally, to elucidate the separate effects of region and species, we sampled stream water $\mathrm{pH}$ at an additional site located in Tacuarembó, Uruguay, where both pines and eucalypts were planted in neighboring catchments.

[14] The Argentinean watersheds were located across the eastern slope of the Córdoba Hills $\left(31^{\circ} \mathrm{S}, 64^{\circ} \mathrm{W}\right)$ (Figure 1). Annual precipitation there averages $850 \mathrm{~mm}$, occurring mostly between spring and fall (October-April) and mean annual temperature is $14.9^{\circ} \mathrm{C}$. Granitic rocks dominate the lithology of the rolling hills in the region. Localized patches of loessic material deposited in the flattest parts of the landscape also are found in this region, but were mostly absent in our study areas. Soils in the area range from Entisols to Haplumbrepts to Hapludolls and Argiudolls across the gradient from rock outcrops to plains, with Haplaquolls found in the valley bottoms. Soils typically meet bedrock at 10 to $60 \mathrm{~cm}$ depth, and pedogenic carbonates are frequently found where the soils are deeper. Study watersheds ranged from 14 to 142 ha (mean watershed size: $63 \mathrm{ha})$ and were located between 1000 and $1900 \mathrm{~m}$ elevation. Grasslands, with a mixed composition of $\mathrm{C}_{3}$ and $\mathrm{C}_{4}$ species, cover the area and are used primarily for cattle and sheep grazing [Cabido, 1985]. Most afforested plots in the region were established in the late 1970s as a result of a tax deferral plan implemented by the Córdoba government. Pinus elliottii is the dominant tree in these plantations followed by $P$. radiata and $P$. ponderosa.

[15] The Uruguayan study sites were located near Minas $\left(34^{\circ} 22^{\prime} \mathrm{S}, 55^{\circ} 14^{\prime} \mathrm{W}\right)$, the capital of Lavalleja department in southeastern Uruguay (Figure 1). Mean annual precipitation is $1150 \mathrm{~mm}$ and mean annual temperature is $16.5^{\circ} \mathrm{C}$. The region is characterized by gentle hills, with a maximum altitude of approximately $500 \mathrm{~m}$. Soils in the region are developed over granitic rock that emerges in some portions of the landscape and include Udolls, Udalfs and occasionally Udepts. Soils at our study sites were mostly Hapludalfs with saprolite contact usually at or near $30 \mathrm{~cm}$. Soils are rich in base cations, and have intermediate fertility and organic carbon contents. In lower portions of the landscape soils are typically deeper, with an argillic horizon and higher organic matter contents (Argiudolls) [Duran, 1985], while stones or gravel are often present throughout the soil profile. Study watersheds ranged from 6.3 to 148 ha (mean watershed size: $39 \mathrm{ha}$ ) and were located between 50 and $200 \mathrm{~m}$ elevation. Most of the region is covered with native grasslands of mixed $\mathrm{C}_{3}$ and $\mathrm{C}_{4}$ composition that, like the Córdoba site, are used for cattle and sheep grazing. Afforested plots were established between 1992 and 1996 and are mainly planted with Eucalyptus globulus and, less frequently, with E. grandis. Streamflow tended to be higher in the grassland streams than in the plantation streams on all sampling dates, although variability was large and differences between them were not significant (Table 1). 
Table 1. Average Streamflow at the Lavalleja, Uruguay, Sites ${ }^{\mathrm{a}}$

\begin{tabular}{lcc}
\hline \multicolumn{1}{c}{ Date } & Grassland & Plantation \\
\hline Aug 2004 & $0.57(0.25)$ & $0.26(0.25)$ \\
Oct 2004 & $0.43(0.25)$ & $0.26(0.25)$ \\
Jun 2005 & $1.75(0.25)$ & $1.57(0.25)$ \\
Aug 2005 & $0.23(0.25)$ & $0.14(0.25)$ \\
Feb 2006 & $0.06(0.25)$ & $0.01(0.32)$ \\
\hline
\end{tabular}

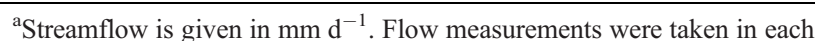
stream at the time of collection of samples for chemical analysis, and the mean flow for all grassland and all plantation sites for each sampling date was calculated. Standard error is given in parentheses.

[16] Finally, additional sampling was done in the Tacuarembó region, located in the northern part of Uruguay (Figure 1). There, MAP is approximately $1450 \mathrm{~mm}$, MAT is $18^{\circ} \mathrm{C}$, and soils are deep $(>1 \mathrm{~m})$, well drained, and have high sand contents (more than 70\%) [Duran, 1985]. The sampled watersheds had gentle slopes $(8-15 \%)$ and the soils were Hapludalfs or Hapludults. These soils developed over noncalcareous quartz sandstone, and typically have low base saturation, low fertility, and low organic carbon, but high water holding capacities. Hapludalfs usually have higher clay contents below $70-100 \mathrm{~cm}$, but are still very well drained. In this area, plantation species are Pinus elliottii, $P$. taeda, and E. grandis planted in a matrix of grazed grasslands with a high proportion of $\mathrm{C}_{4}$ grasses.

\subsection{Field and Laboratory Methods}

[17] We took triplicate water samples from streams originating in adjacent grassland and plantation watersheds on six dates, covering fall, winter, and spring sampling dates during two successive years from 2004 to 2006. Sampling was done during low-flow. Samples were collected with $60 \mathrm{~mL}$ syringes that were rinsed three times with stream water, then immediately filtered through $0.45 \mu \mathrm{m}$ filters and stored in high-density polyethylene bottles that had been prewashed six times in ultrapure deionized water. Samples for alkalinity analysis were collected in bottles that were rinsed three times with stream water then filled completely and capped underwater. All samples were kept cool and refrigerated until analysis at Duke University (Durham, North Carolina). Stream samples were analyzed for concentrations of total dissolved $\mathrm{C}$, dissolved organic $\mathrm{C}$, and total dissolved $\mathrm{N}$ on a Shimadzu TOC-Vcph with a TNM-1 module. Cations were analyzed on an ICP at Utah State University's Analytical Laboratory (USUAL, Logan, UT). Alkalinity was measured by titration of unfiltered samples with $0.01 \mathrm{M} \mathrm{HCl}$ to an end point of $\mathrm{pH} 5.0$ using a Brinkman titrator fitted with a combination electrode. We measured temperature, conductivity, and $\mathrm{pH}$ in the field with an Accumet meter (Fisher Scientific) and streamflow with a portable flowmeter with an electromagnetic velocity sensor (Flo-Mate Model 2000, Marsh-McBirney, Inc.). In the case of Tacuarembó, this field sampling was done in three blocks, each of which included grassland, pine, and eucalyptus catchments established over the same soil units.

[18] At 7 of the 8 sites in Lavalleja, Uruguay, we collected soil samples at six roughly equidistant points along a transect $(300-700 \mathrm{~m})$ running from ridge to ridge and approximately perpendicular to the stream in each of the catchments (although there were 8 watersheds, one site had been cut at the time of soil sampling and could no longer be used). Samples were collected with a corer at depths of $0-10 \mathrm{~cm}, 10-20 \mathrm{~cm}$, and $20-30 \mathrm{~cm}$. Separate samples were collected for bulk density measurements. Soils were air dried and large roots and stones were removed and measured for volume. Samples were sieved through $2 \mathrm{~mm}$ mesh after grinding with a pestle and mortar to disrupt large clay aggregates where necessary.

[19] Exchangeable cations were extracted with $1 \mathrm{M}$ ammonium acetate in a 1:20 soil-to-solution ratio at $\mathrm{pH} 7$. Soil and extracting solutions were shaken for thirty minutes and then filtered through Whatman number 42 filter papers. The filtered extractant was stored below $4{ }^{\circ} \mathrm{C}$ for analysis using atomic absorption spectrometry (AAS) for calcium $(\mathrm{Ca})$, magnesium $(\mathrm{Mg})$, sodium $(\mathrm{Na})$ and potassium $(\mathrm{K})$. The moisture content of randomly selected samples was found to be less than $3 \%$ on average. Consequently, concentrations of soil cations are expressed as mass per unit weight of air-dried soil ( $\mathrm{mg} \mathrm{g}^{-1}$ ) and no adjustment was made for soil moisture. Soil $\mathrm{pH}$ was measured in 1:1 weight to volume ratio with deionized water.

\subsection{Statistical Methods}

[20] Statistical analysis for the regional stream survey was done using one-way ANOVAs for each pair of catchments, with vegetation type as the factor. In these analyses, samples from all of the sampling dates were pooled for each site and grassland streams and plantation streams were compared. For the local analysis (including only samples from the Lavalleja, Uruguay sites), statistical analysis of stream samples was done using two-way analysis of variance, with vegetation type and date of sampling as the factors. This assumes that samples taken several months apart from the same stream are independent, an assumption that is justified on the basis of the long time lag between sampling dates ( 2 months or more) and the fact that the streams sampled drained fairly low relief catchments and were all sampled under low-flow conditions. For soil samples, the values for the 6 samples from each site were pooled and one-way analysis of variance was performed for each of the three soil depths $(0-10 \mathrm{~cm}, 10-20 \mathrm{~cm}$, and $20-30 \mathrm{~cm}$ ), with vegetation type as the main factor. In cases where the assumption of homogeneity of variances was not met, nonparametric Kruskal-Wallis tests were used (in all cases producing the same result as the ANOVA). For the site-specific analysis, we used two-way ANOVA, with vegetation type and sampling block as the factors, and a REGWF (Ryan-Einot-Gabriel-Welsch F) post hoc test.

\section{Results}

\subsection{Regional Analysis: Uruguay and Argentina}

[21] Stream $\mathrm{pH}$ decreased substantially with grassland afforestation ( $p<0.001$, Figure 2). Overall, stream $\mathrm{pH}$ in plantations was 0.4 units lower on average than in grasslands. When separated out by region and species, however, most of this difference was driven by the sites in Uruguay, where stream $\mathrm{pH}$ was 0.7 units lower on average in eucalypt plantations than in grasslands $(p<0.001)$. In the most extreme cases, stream $\mathrm{pH}$ dropped by almost a full $\mathrm{pH}$ unit (Figure 2). In contrast, the pattern at the Argentina sites planted with pine was less obvious; in only one of the paired 
Uruguay Catchments

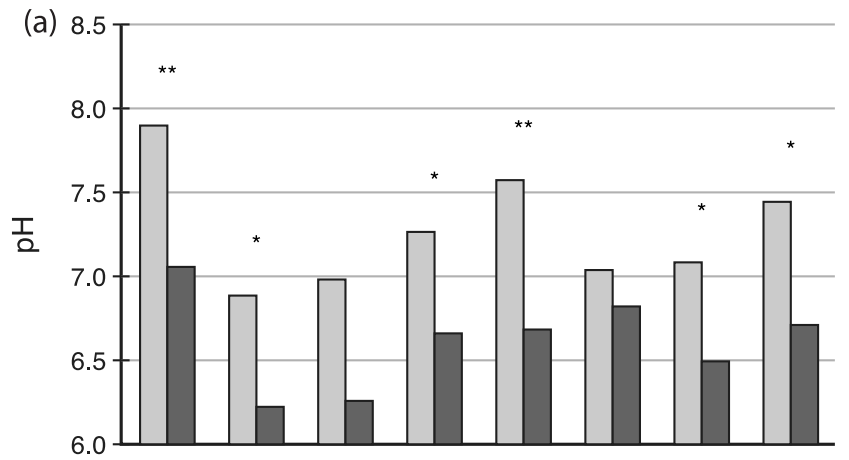

Argentina Catchments

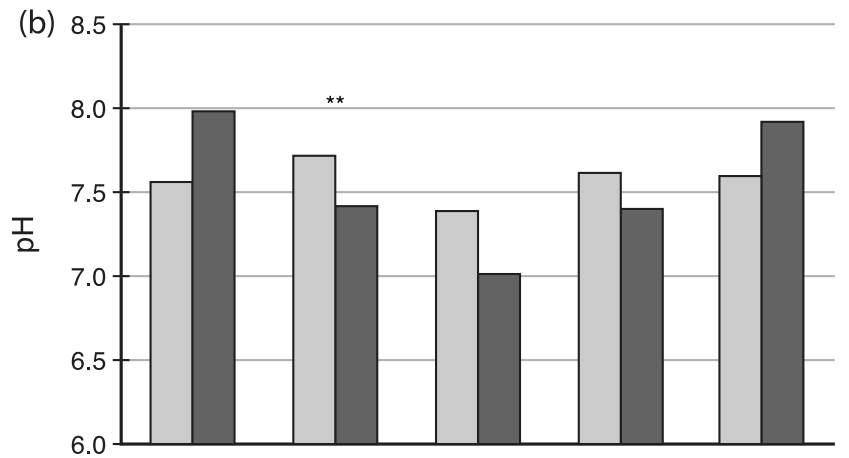

Grassland

Plantation

Figure 2. Regional stream $\mathrm{pH}$ for grassland and plantation pairs in (a) Lavalleja, Uruguay, and (b) Córdoba, Argentina. Asterisks indicate the following: $* * p<0.01,{ }^{*} p<0.05$.

catchments was $\mathrm{pH}$ significantly lower in the plantation stream than in the grassland (Figure 2).

\subsection{Detailed Local Analysis: Lavalleja, Uruguay}

[22] Along with the average decrease in stream $\mathrm{pH}$ of 0.7 units, levels of $\mathrm{Ca}, \mathrm{Mg}, \mathrm{K}, \mathrm{Na}, \mathrm{DIC}$, and alkalinity in plantation streams also dropped between 41 and $54 \%$ compared to grassland streams $(p<0.01$ in all cases, Figure 3 ). The differences in chemistry between grassland and plantation streams were consistent at different times of the year, whether solute and DIC concentrations were low (as in early winter) or high (as at the end of the growing season) (Table 2). Ca, in particular, showed strong seasonal variation, with the highest concentrations at the end of summer for both grasslands and plantations but with significantly higher concentrations in grasslands at all times of the year (Table 2). There was no significant interaction between vegetation type and sampling date for any of the variables, confirming that the differences between grasslands and plantations do not depend on the season of sampling (Table 2).

[23] Changes in soil properties with afforestation were similar to those measured in the streams. In watersheds planted with eucalyptus, $\mathrm{Ca}, \mathrm{Mg}$, and $\mathrm{Na}$ were more than $30 \%$ lower in afforested soils than in grassland soils and $\mathrm{pH}$ was $0.2-0.3$ units lower in plantation soils below $10 \mathrm{~cm}$ depth $(p<0.05$ in all cases, Figures $4 \mathrm{a}-4 \mathrm{e})$. When examined by pool sizes rather than concentrations, the patterns were also similar. Grassland soils tended to have larger pools of $\mathrm{Ca}, \mathrm{Mg}$, and $\mathrm{Na}$ at all three depths sampled, while $\mathrm{K}$ pools tended to be larger in plantation soils, although the variability was large. While these differences were not significant overall, they suggest a trend toward a decline in pools of most soil cations under plantations (Table 3).

\subsection{Site-Specific Analysis: Tacuarembó, Uruguay}

[24] At the Tacuarembó site in Uruguay, where both pine and eucalyptus are planted in the same area, eucalypt plantations had much stronger effects on stream $\mathrm{pH}$ than did pine plantations (Figure 5). Stream $\mathrm{pH}$ was 0.6 units lower in streams draining eucalyptus than those draining grasslands $(p=0.003)$, while pines tended to acidify the streams by only $0.2 \mathrm{pH}$ units and the difference with grasslands was not significant ( $p=0.09$, Figure 5). Because both pine and eucalyptus were present at this site, it allowed us to compare directly the effects of planting with different tree species. These results suggest that eucalyptus has a much stronger acidifying effect than pine and that the species planted may play a more important role in determining the effect of plantations on stream chemistry than regional differences in soil characteristics.

\section{Discussion}

\subsection{Hydrologic and Biogeochemical Pathways to Change Following Afforestation}

[25] The two mechanisms of change in stream cation concentrations we have proposed include hydrologic alteration and biogeochemical change through increased nutrient retention or mobilization (Figure 6). Afforestation is expected to lead to a reduction in streamflow, and plantation streams in Uruguay tended to have lower flow than grassland streams [Farley et al., 2005; Jackson et al., 2005]

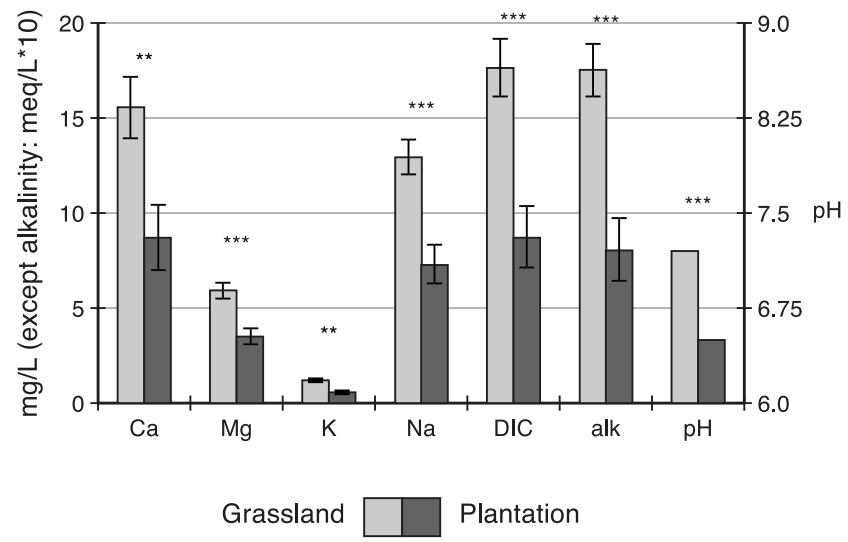

Figure 3. Stream solute concentrations in Lavalleja, Uruguay. Bars represent means for all grassland sites and all plantation sites at eight sites sampled over all six sampling dates (plus or minus standard error). Values for $\mathrm{Ca}, \mathrm{Mg}, \mathrm{K}, \mathrm{Na}$, and DIC are in $\mathrm{mg} \mathrm{L}^{-1}$; values for alkalinity (alk) are in meq $\mathrm{L}^{-1} \times 10$. Asterisks indicate the following: $* * * p<0.001, * * p<0.01$. 
Table 2. Stream Solute Concentrations Across Sampling Dates in Lavalleja, Uruguay ${ }^{\mathrm{a}}$

\begin{tabular}{|c|c|c|c|c|c|c|c|c|c|c|c|c|}
\hline & \multicolumn{2}{|c|}{ DIC } & \multicolumn{2}{|c|}{$\mathrm{Ca}$} & \multicolumn{2}{|c|}{$\mathrm{Na}$} & \multicolumn{2}{|c|}{$\mathrm{Mg}$} & \multicolumn{2}{|c|}{ K } & \multicolumn{2}{|c|}{$\mathrm{pH}$} \\
\hline & G & $P$ & G & $P$ & G & $\mathrm{P}$ & G & $P$ & G & $\mathrm{P}$ & G & $\mathrm{P}$ \\
\hline May 2004 & $11.7(3.9)$ & $6.2(3.9)$ & $11.9(4.3)$ & $7.4(4.3)$ & $10.3(2.5)$ & $7.1(2.5)$ & $3.8(1.1)$ & $2.6(1.1)$ & $0.9(0.4)$ & $0.3(0.4)$ & 6.8 & 6.2 \\
\hline Aug 2004 & $18.2(3.3)$ & $10.2(3.3)$ & $14.3(3.8)$ & $8.1(3.8)$ & $11.7(2.2)$ & $7.1(2.2)$ & $4.5(1.0)$ & $2.4(1.0)$ & $0.6(0.3)$ & $0.0(0.3)$ & 7.6 & 7.0 \\
\hline Oct 2004 & $17.3(3.3)$ & $8.8(3.3)$ & $13.2(3.8)$ & $7.1(3.8)$ & $11.7(2.2)$ & $6.9(2.2)$ & $4.9(1.0)$ & $2.9(1.0)$ & $1.1(0.3)$ & $0.9(0.3)$ & 7.4 & 6.9 \\
\hline Jun 2005 & $9.4(3.3)$ & $3.8(3.6)$ & $8.0(3.8)$ & $5.5(4.0)$ & $7.1(2.2)$ & $5.9(2.3)$ & $3.4(1.0)$ & $2.5(1.0)$ & $0.5(0.3)$ & $0.0(0.3)$ & 7.1 & 6.6 \\
\hline Aug 2005 & na & na & $19.3(3.8)$ & $10.3(4.0)$ & $15.7(2.2)$ & $8.5(2.3)$ & $8.0(1.0)$ & $4.6(1.0)$ & $1.3(0.3)$ & $0.9(0.4)$ & 7.5 & 6.6 \\
\hline Feb 2006 & $31.5(3.3)$ & $14.6(4.2)$ & $26.5(3.8)$ & $14.0(4.8)$ & $20.8(2.2)$ & $8.1(2.8)$ & $10.9(1.0)$ & $6.1(1.2)$ & $2.8(0.3)$ & $1.8(0.4)$ & 7.0 & 6.3 \\
\hline Mean & $17.6(1.5)$ & 8.7 (1.6) & 15.5 (1.6) & $8.7(1.7)$ & $12.9(0.9)$ & $7.3(1.0)$ & $5.9(0.04)$ & $3.5(0.4)$ & $1.2(0.1)$ & $0.6(0.1)$ & 7.2 & 6.5 \\
\hline $\operatorname{Veg} p$ & 0.001 & & 0.004 & & 0.001 & & 0.001 & & 0.004 & & 0.001 & \\
\hline Date $p$ & 0.001 & & 0.03 & & 0.02 & & 0.001 & & 0.001 & & 0.001 & \\
\hline Veg $\mathrm{x}$ date $p$ & 0.55 & & 0.87 & & 0.25 & & 0.44 & & 0.88 & & 0.92 & \\
\hline
\end{tabular}

${ }^{\mathrm{a}} \mathrm{G}$, grassland; P, plantation; DIC, dissolved inorganic carbon; na, not available. Concentrations are given in $\mathrm{mg} \mathrm{L}^{-1}$. Standard error is given in parentheses.

(Table 1). Therefore, it might be expected that afforestation, with lower streamflow and less dilution, would lead to higher cation concentrations in plantation streams (Figure 6, far left pathway). However, cation concentrations decreased following afforestation in Uruguay despite the reduction in streamflow, suggesting that cations accumulated in tree biomass and the mechanism behind the change was increased nutrient retention (Figure 6, darker shaded box). The fact that this occurred despite decreased flow indicates that the lower cation concentrations in plantation streams actually provide a low estimate of the amount of cation redistribution, and that the difference between grasslands and plantations would be even larger if considered as a flux rather than a concentration.

[26] Calcium retention in afforested watershed can be accounted for by the sequestration of this element in tree biomass, as suggested by the following rough estimate. Assuming that our flow estimates for the period of sampling represent the average flow, total calcium export would have reached $24.7 \mathrm{~kg} \mathrm{ha}^{-1} \mathrm{a}^{-1}$ for grasslands versus $10.3 \mathrm{~kg} \mathrm{ha}^{-1} \mathrm{a}^{-1}$ from the plantation streams. Given that retention rates of $118 \mathrm{~kg} \mathrm{ha}^{-1} \mathrm{a}^{-1}$ have been described for eucalyptus plantations in the Pampas [Jobbágy and Jackson, 2003], the difference of $14.4 \mathrm{~kg} \mathrm{ha}^{-1} \mathrm{a}^{-1}$ in plantation streams could very plausibly be the result of Ca sequestration in the tree biomass. Although this is a conservative estimate, given that it is based on measurements taken during low flow and does not account for exports during stormflows, the relative difference between grasslands and plantations is clear. This rough calculation demonstrates that the $\mathrm{Ca}$ sequestration potential of trees is much greater than the losses documented from plantation streams and, even if $\mathrm{Ca}$ exports were an order of magnitude larger when including stormflows, this mechanism could account for chemical shifts in stream water in the range observed following afforestation.

\subsection{Terrestrial-Aquatic Links}

[27] In addition to providing new information on the mechanisms that drive acidification following tree establishment, our results indicate that the effects of afforestation on soils are propagated to streams. Soil acidification following afforestation can be produced through three primary mechanisms, including increased inputs of organic acids, increased soil respiration, or increased uptake of cations by plantation trees [Jobbágy and Jackson, 2003]. Each of these mechanisms is expected to produce a different pattern of acidification in the soil profile. In the case of cation redistribution, maximum acidification occurs below $10 \mathrm{~cm}$ depth, where nutrient uptake is highest but inputs from throughfall and litter are low [Jobbágy and Jackson, 2003]. The pattern of acidification of soils under eucalyptus in Uruguay is consistent with this mechanism, as demonstrated by lower $\mathrm{pH}$ below $10 \mathrm{~cm}$ depth under plantations, with no significant change in $\mathrm{pH}$ between 0 and $10 \mathrm{~cm}$ depth (Figure 4e).

[28] Our results coincide with the idea that cation accumulation in biomass is an important source of soil acidification following afforestation, as $\mathrm{Ca}$ and other exchangeable cations are redistributed from the soil pool to the tree biomass [Brand et al., 1986; Binkley et al., 1989; Jobbágy and Jackson, 2003; Farley and Kelly, 2004]. The reduction in soil cation concentrations under eucalyptus in Uruguay was particularly large in the case of $\mathrm{Ca}$, but was also significant for $\mathrm{Mg}$ and $\mathrm{Na}$ (Figures $4 \mathrm{a}-4 \mathrm{~d}$ ). The decrease in soil $\mathrm{Na}$ under plantations in Uruguay contrasts with most cases included in a global synthesis, where the trend was for $\mathrm{Na}$ to become concentrated in soils following afforestation, likely because of exclusion by roots [Jackson et al., 2005]. The reason for this difference is uncertain, but may be related to the initial concentration of $\mathrm{Na}$ in the soil or to differences in uptake among tree species. Unlike the soils included in the global synthesis, the Uruguayan soils had low initial $\mathrm{Na}$ concentrations that may have become depleted by tree uptake and storage during plantation establishment. Furthermore, differences in the use and tolerance of $\mathrm{Na}$ between eucalyptus and other plantation species, as well as among species of eucalyptus, likely exist [Marcar and Termaat, 1990].

[29] Comparison of soils under grasslands and plantations allows for a better understanding of the vertical redistribution of cations following afforestation, while the addition of stream sampling provides complementary information on whether a lateral redistribution of cations also occurs following this land use change, and provides the opportunity for coarse-scale spatial integration. Under the first two mechanisms of soil acidification, organic acid input and soil respiration, cation leaching with a corresponding increase in stream cation concentrations would be expected in the shorter term (Figure 6, far right pathway). However, if the third mechanism, cation redistribution, dominates, an in- 


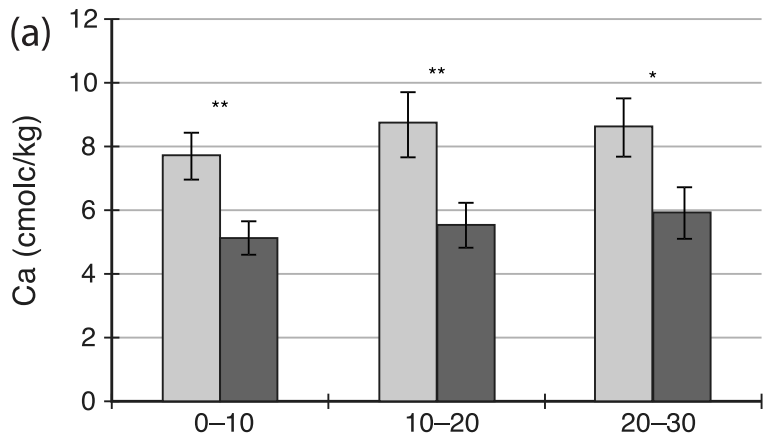

Soil Depth $(\mathrm{cm})$

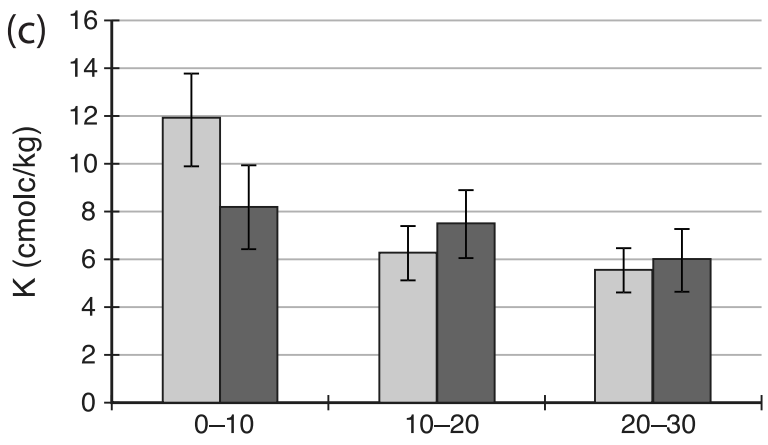

Soil Depth $(\mathrm{cm})$

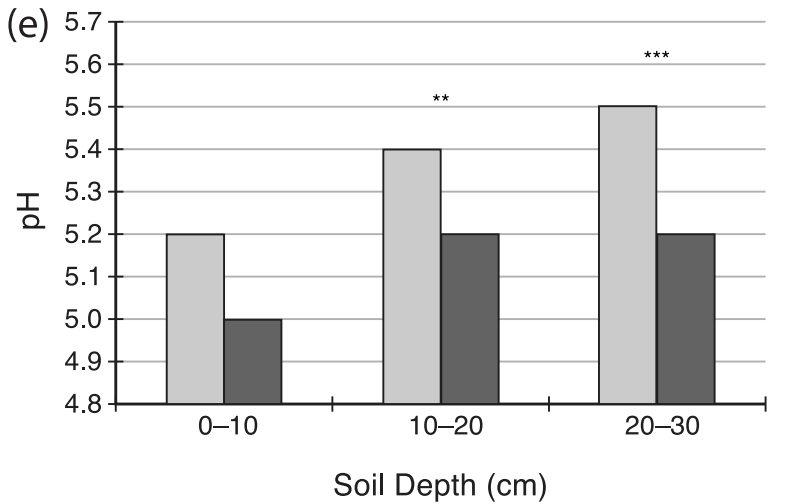

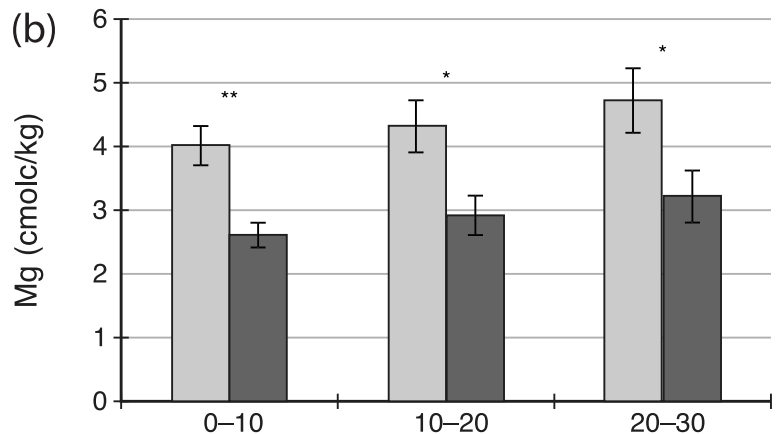

Soil Depth $(\mathrm{cm})$

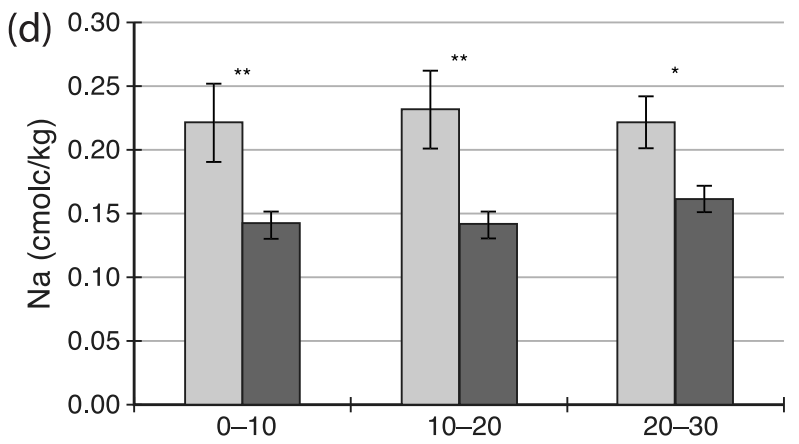

Soil Depth $(\mathrm{cm})$
Grassland

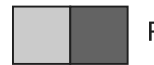

Plantation

Figure 4. Soil exchangeable cations, including concentrations of $\mathrm{Ca}, \mathrm{Mg}, \mathrm{K}$, and $\mathrm{Na}$ (centimoles of charge per kilogram) (plus or minus standard error) and $\mathrm{pH}$ in Lavalleja, Uruguay. Asterisks indicate the following: $* * p<0.01, * p<0.05$.

crease in cations in stream water would not be expected because soil cations would be redistributed to the tree biomass rather than leached from the soil (Figure 6, middle pathway). The pattern of soil acidification following euca- lyptus establishment in Uruguay follows the cation redistribution model, while further evidence that this is the dominant mechanism comes from the lower cation concentrations in streams draining plantations (Figure 6, darker

Table 3. Soil Exchangeable Cation Pools in Lavalleja, Uruguay ${ }^{\mathrm{a}}$

\begin{tabular}{|c|c|c|c|c|c|c|c|c|}
\hline \multirow[b]{2}{*}{ Soil Depth } & \multicolumn{2}{|c|}{$\mathrm{Ca}$} & \multicolumn{2}{|c|}{$\mathrm{Mg}$} & \multicolumn{2}{|c|}{ K } & \multicolumn{2}{|c|}{$\mathrm{Na}$} \\
\hline & G & $\mathrm{P}$ & G & $\mathrm{P}$ & G & $\mathrm{P}$ & G & $\mathrm{P}$ \\
\hline $0-10 \mathrm{~cm}$ & $542(79)$ & 459 (95) & $288(42)$ & $229(45)$ & $24.5(1.9)$ & $27.6(3.1)$ & $15.6(2.7)$ & $12.0(0.7)$ \\
\hline $10-20 \mathrm{~cm}$ & 729 (147) & $542(140)$ & $355(60)$ & $286(67)$ & $16.5(1.5)$ & $21.2(3.2)$ & $19.2(3.3)$ & $13.4(1.1)$ \\
\hline $20-30 \mathrm{~cm}$ & 772 (118) & $673(175)$ & 418 (69) & 356 (89) & $15.8(1.5)$ & $20.1(3.3)$ & $20.0(2.6)$ & $16.7(1.6)$ \\
\hline
\end{tabular}

${ }^{\mathrm{a}} \mathrm{G}$, grassland; P, plantation. Averages were calculated for each vegetation/depth combination at seven of the sites $(n=7$ for each cell; mean \pm standard error) and are given in centimoles of charge per meter. 


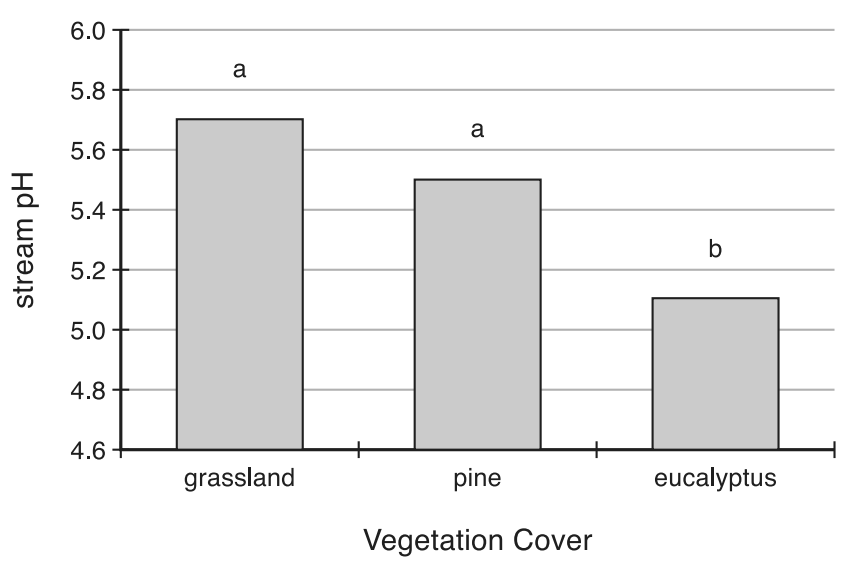

Figure 5. Stream $\mathrm{pH}$ at the Tacuarembó site in Uruguay. Bars with different letters are significantly different $(p<0.05)$.

shaded box). Concentrations of $\mathrm{Ca}, \mathrm{Mg}, \mathrm{K}$, and $\mathrm{Na}$ were all significantly higher in streams draining grasslands than those draining plantations, suggesting that the cations lost from soils under eucalyptus were redistributed to the veg- etation rather than leached. Part of the decrease in stream cation concentrations can be attributed to the decrease in bicarbonate ions, the dominant anion in these streams, in order to preserve electroneutrality. Given the decrease in stream $\mathrm{pH}$, however, it seems that soil stores of base cations are not sufficient to balance even the reduced anion concentrations and the charge balance is maintained by $\mathrm{H}^{+}$ leaching (Figure 6, middle pathway).

[30] The fact that stream cation concentrations mirror the lower cation concentrations in plantation soils suggests that the changes are the result of the redistribution of cations from soil pools to vegetation pools. However, another possible contributor to the change in stream chemistry is the alteration of flow paths. These changes may occur following afforestation because of differences in bulk density and rooting patterns between grassland and plantation watersheds. Bulk density was higher in plantation soils than grassland soils, suggesting either a reduction in pore volume or a reduction in organic matter content, either of which would influence the water holding capacity of soils and the rate and degree to which water infiltrates. In addition, rooting patterns are altered with afforestation, with tree

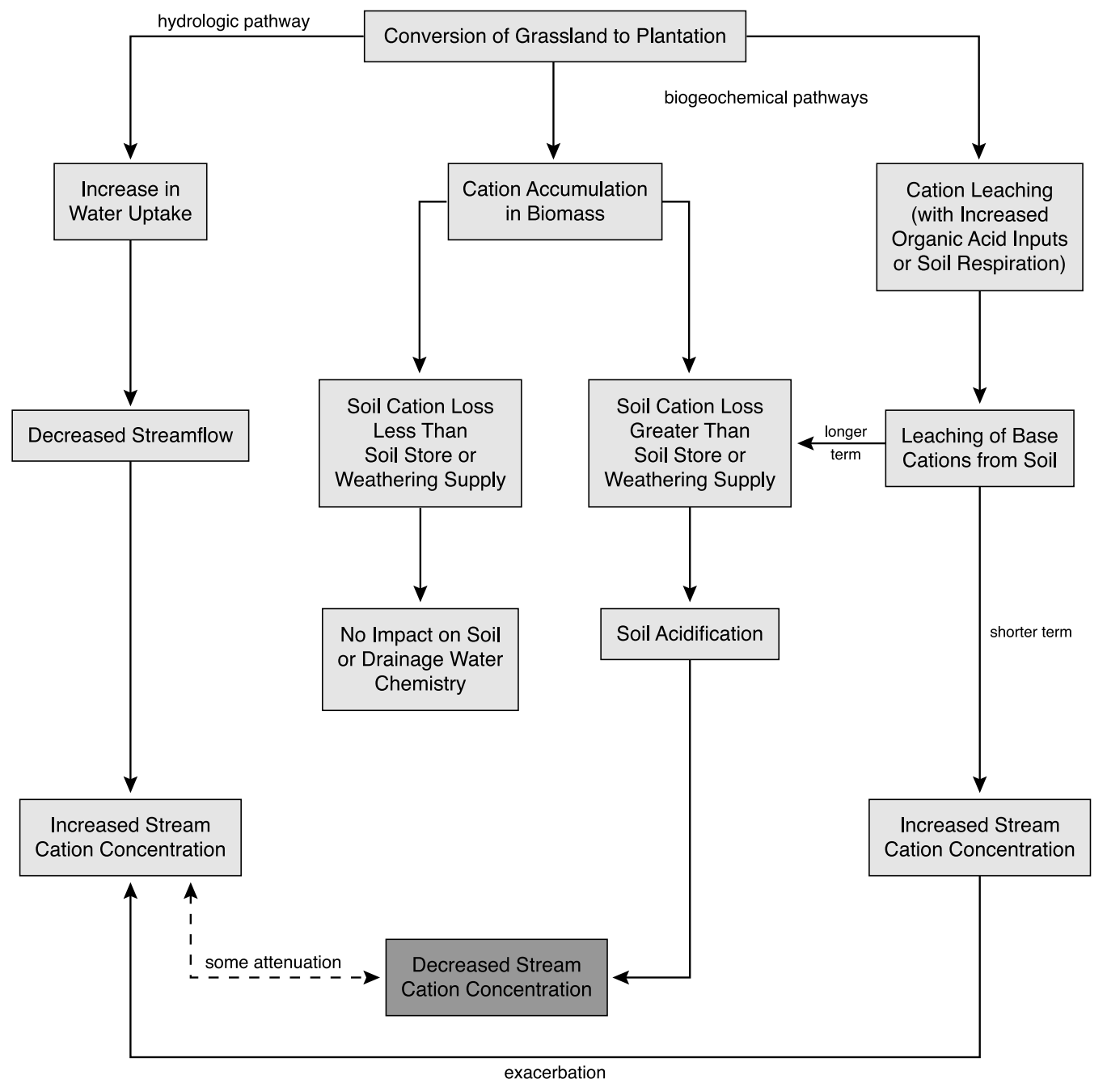

Figure 6. Pathways to change in stream acidity. Changes in stream acidity can occur via hydrologic as well as biogeochemical pathways, and these pathways can interact to attenuate or exacerbate changes. The outcome observed in Uruguay is in the darker shaded box. 
roots generally reaching deeper into the soil than those of grasses and, in some cases, breaking soil structure, so that water is transferred rapidly to deeper soil layers [Guo and Gifford, 2002; Schenk and Jackson, 2002; Farley et al., 2004]. This rapid transfer through macropore networks created by tree roots would reduce the opportunity for low ionic strength waters to equilibrate with the soil matrix, resulting in lower concentrations of solutes in runoff than might be expected in soils dominated by the finer roots of grassland plants.

[31] Links between soils and streams also likely play an important role in the observed change in DIC following afforestation. While it is possible that DIC is lost from afforested streams because of degassing of $\mathrm{CO}_{2}$ from shallow waters, at the $\mathrm{pH}$ range of streams in our study sites $(6.2-7.6)$ most of the inorganic carbon will be present as $\mathrm{HCO}_{3}^{-}$or $\mathrm{CO}_{3}^{2-}$ rather than dissolved $\mathrm{CO}_{2}$. It is more likely that the decrease in stream water DIC in afforested catchments is soil mediated, either as a consequence of degassing at the surface of drier soils, or due to a reduction in soil and root respiration. Although the mechanism is not certain, our rough calculations (based on the same criteria used for Ca above) suggest that the quantities are substantial, with plantation streams exporting in the range of $18 \mathrm{~kg}$ $\mathrm{ha}^{-1} \mathrm{a}^{-1}$ less DIC than grassland streams. This alteration in the transport of terrestrial carbon to aquatic systems can affect regional carbon balances by altering the amount of $\mathrm{C}$ buried and stored in sediments and transported to the ocean [Cole et al., 2007].

\subsection{Role of Region Versus Species in Response to Afforestation}

[32] The study regions in Argentina and Uruguay are characterized by different climates and soils, as well as different plantation species. While there was little change in stream chemistry under pine plantations in Argentina, there were significant differences following establishment of eucalyptus in Uruguay. This suggests that the differences in climate and soil may play a role in mediating, and, in Argentina, possibly ameliorating, the effects of vegetation change. However, it also leaves open the possibility that the differences between the two regions were a result of the species planted. Our results from the third region, Tacuarembó, Uruguay, suggest that there are differences in the uptake of cations between pines and eucalyptus, indicating that the species of tree planted may play a more important role than regional characteristics. The uptake of $\mathrm{Ca}$ and $\mathrm{Mg}$ has been found to be greater under eucalyptus than under pine [Huang and Bachelard, 1993], and may partially explain the differences in acidification between species at the Tacuarembó site. Greater acidification of streams under eucalyptus would be expected with greater $\mathrm{Ca}$ and $\mathrm{Mg}$ uptake and may result in eucalyptus being a stronger acidifier as a plantation species than pine. However, further research in locations where both species exist is required to provide a better and more detailed understanding of the species effect.

\section{Implications and Conclusions}

[33] Our stream data provide a complement to the current understanding of vertical redistributions of cations by adding a lateral dimension, providing insight into the ways in which afforestation can be expected to affect future site productivity. Under grasslands, fewer cations are retained in the biomass, leaving higher concentrations in soils, which are then reflected in higher stream water loads. Tree establishment triggers a strong redistribution of cations to biomass leading to lower concentrations in both soils and stream water. It could appear that cations are being exported either way - with export occurring via streams in the case of grasslands and via biomass in the case of plantations. For this reason, it is important to look at cation pools in the soils as well as concentrations. Cation contents remained large in soils draining grasslands despite the high concentrations in streams, suggesting that the store of soil cations is unaffected by hydrologic cation export. In contrast, decreasing soil cation contents under plantations suggest that cation export through biomass is beginning to deplete the soil store of base cations. The difference in soil $\mathrm{Ca}$ contents between grasslands and plantations is approximately $700 \mathrm{~kg} \mathrm{ha}^{-1}$, which equates to a loss of between 54 and $78 \mathrm{~kg} \mathrm{ha}^{-1} \mathrm{a}^{-1}$ from soils under plantations, or $741-1066 \mathrm{~kg} \mathrm{ha}^{-1}$ over a full rotation (plantations were 9-13 years old in 2005 and are typically harvested around 13 years). Given a $\mathrm{Ca}$ retention rate of $118 \mathrm{~kg} \mathrm{ha}^{-1} \mathrm{a}^{-1}$, over a 13-year rotation, eucalyptus would be expected to retain approximately $1500 \mathrm{~kg} \mathrm{ha}^{-1}$ of $\mathrm{Ca}$, approximately half of which is being met through depletion of soil $\mathrm{Ca}$ stores. These numbers indicate that even one rotation will have a substantial effect on soil fertility and that soil Ca stores may not meet the needs of a second rotation. The amount being incorporated into biomass, and ultimately destined for timber or paper products, is much larger than that exported in streams, according to our rough mass balance estimates. The export in biomass then becomes permanent as trees are harvested and the cations are removed from the ecosystem, so that repeated cycles of harvesting and replanting could result not only in a loss of soil fertility, but also persistent soil acidity which can remain for decades after harvesting [Alfredsson et al., 1998]. The persistence of acidity is likely to be exacerbated by the decrease in alkalinity following afforestation, as buffering capacity in these soils is lost and they become more susceptible to further changes in $\mathrm{pH}$.

[34] In addition to effects on site productivity, acidification and changes in stream cation concentrations also have implications for water quality and the diversity and viability of aquatic species, in particular invertebrate communities and fish populations [Kelly-Quinn et al., 1996; Friberg et al., 1998; Giller and O'Halloran, 2004]. Most of the existing research on these issues comes from northern Europe. For example, in a study of spruce plantations in Scotland, trout were found to be absent from the more acidic forested streams, and salmon eggs planted in those streams died within weeks [Harriman and Morrison, 1982]. Others have found that trout are particularly sensitive to changes in calcium, alkalinity, and $\mathrm{pH}$, with $\mathrm{Ca}$ playing an important role in influencing the ability of fish to tolerate high aluminum levels [Kelly-Quinn et al., 1996; McClurg et al., 2007]. The interactions among stream variables can be particularly key in influencing fish survival and reproduction; in the case of acidic streams in Norway, stream calcium concentrations and the ratio of calcium to $\mathrm{H}^{+}$ were the strongest determinants of brown trout density [Hesthagen et al., 1999]. While the species of interest in 
northern Europe are different than those in southern South America, the significant changes in these variables in streams draining plantations in Uruguay suggest that afforestation may also have impacts for aquatic species of interest in this region.

[35] Although our data exploring pine versus eucalypt impacts are preliminary, our results suggest that the choice of both site and species for afforestation programs are important determinants in making plantation forestry a sustainable land use. Other researchers have suggested that the species planted can play a key role in the degree of surface water acidification following afforestation, and our results are consistent with that idea [Waters and Jenkins, 1992]. Further research is needed to confirm whether eucalyptus acts as a stronger acidifier than pine, and whether the appearance of this difference depends on the soils and geology of the site being planted.

[36] Much of the previous research on the effects of afforestation on stream chemistry has been conducted in Ireland and the U.K., particularly in regions with high levels of acid deposition [Allott et al., 1993; Giller and O'Halloran, 2004]. However, very little research has been done in the regions of the world that have become the most important new fronts for afforestation. Yet, an understanding of the relationship between land use and water quality is necessary in order to provide land owners and managers with the information needed for improved land management [Baker, 2003]. One of the challenges of sustainable land use and management is that of "reducing the negative environmental impacts of land use while maintaining economic and social benefits" [Foley et al., 2005, p. 570]. In order to do this, the trade-offs among alternative land uses must be understood, including the suites of ecosystem goods and services each land use provides, and those that they compromise. Although plantations contribute to timber production and carbon sequestration, the trade-off with other ecosystem services, such as water quantity and quality, should continue to be evaluated in order to maximize the conditions under which this important land use can be sustainable over the long term.

[37] Acknowledgments. Funding for this work was provided by the National Science Foundation (Biological Sciences grant 0717191), the Inter-American Institute for Global Change Research (IAI) (CRN II 2031), which is supported by the U.S. National Science Foundation (grant GEO-0452325), and the project "SENSOR TTC." We thank Juan Manuel Piñeiro, Matias Carambula, Laura Weinbaum, Pedro Gundel, Marcelo Nosetto, Sean Berthrong, Mike McGowan, and Will Cook for assistance with field and laboratory work and Harry Johnson for producing the figures. We appreciate the helpful comments of Trent Biggs and an anonymous reviewer. We also thank Diego Piñeiro and the Universidad de la República in Uruguay for their support of this project. Finally, we are grateful to the Martirena family, the Ferber family, Elvecia Huelmos de Pereira, Eduardo Coria, Enrique Rodas, Anibal and Cristina Fernandez, Pedro Marmo, and Aldo Rudi for allowing us to conduct research on their properties, for helping us to better understand the history of plantations in this region, and for their hospitality.

\section{References}

Alfredsson, H., L. M. Condron, M. Clarholm, and M. R. Davis (1998), Changes in soil acidity and organic matter following the establishment of conifers on former grassland in New Zealand, For. Ecol. Manage., 112, 245-252, doi:10.1016/S0378-1127(98)00346-6.

Allott, N., M. Brennan, P. Mills, and A. Eacrett (1993), Stream chemistry and forest cover in ten small Western Irish catchments, in Ecological Effects of Afforestation: Studies in the History and Ecology of Afforesta- tion in Western Europe, edited by C. Watkins, pp. 165-177, CAB Int., Wallingford, U. K.

Baker, A. (2003), Land use and water quality, Hydrol. Processes, 17(12), 2499-2501, doi:10.1002/hyp.5140.

Bernhardt, E. S., and G. E. Likens (2002), DOC enrichment alters nitrogen dynamics in a forest stream, Ecology, 83(6), 1689-1700.

Biggs, T. W., T. Dunne, T. F. Domingues, and L. A. Martinelli (2002), Relative influence of natural watershed properties and human disturbance on stream solute concentrations in the southwestern Brazilian Amazon basin, Water Resour. Res., 38(8), 1150, doi:10.1029/2001WR000271.

Biggs, T. W., T. Dunne, and L. A. Martinelli (2004), Natural controls and human impacts on stream nutrient concentrations in a deforested region of the Brazilian Amazon basin, Biogeochemistry, 68, 227-257, doi:10.1023/B:BIOG.0000025744.78309.2e.

Billett, M. F., C. M. Deacon, S. M. Palmer, J. J. C. Dawson, and D. Hope (2006), Connecting organic carbon in stream water and soils in a peatland catchment, J. Geophys. Res., 111, G02010, doi:10.1029/ 2005JG000065.

Binkley, D., D. Valentine, C. Wells, and U. Valentine (1989), An empiricalanalysis of the factors contributing to 20 -year decrease in soil-pH in an old-field plantation of loblolly-pine, Biogeochemistry, 8, 39-54, doi:10.1007/BF02180166.

Brand, D. G., P. Kehoe, and M. Connors (1986), Coniferous afforestation leads to soil acidification in central Ontario, Can. J. For. Res., 16, 13891391, doi:10.1139/x86-248.

Cabido, M. (1985), Las comunidades vegetales de la Pampa de Achala. Sierras de Cordoba, Argentina, Doc. Phytosociol., 9, 431-443.

Calder, I. R. (1986), Water use of eucalypts-A review with special reference to south India, Agric. Water Manage., 11, 333-342, doi:10.1016/ 0378-3774(86)90049-1.

Clenaghan, C., J. O'Halloran, P. S. Giller, and N. Roche (1998), Longitudinal and temporal variation in the hydrochemistry of streams in an Irish conifer afforested catchment, Hydrobiologia, 389, 63-71, doi:10.1023/A:1003567312232.

Cole, J. J., et al. (2007), Plumbing the global carbon cycle: Integrating inland waters into the terrestrial carbon budget, Ecosystems, 10(1), 172-185, doi:10.1007/s10021-006-9013-8.

Cosby, B. J., A. Jenkins, R. C. Ferrier, J. D. Miller, and T. A. B. Walker (1990), Modeling stream acidification in afforested catchments: Longterm reconstructions at 2 sites in central Scotland, J. Hydrol., 120(1-4), 143-162, doi:10.1016/0022-1694(90)90147-P.

DeFries, R. S., J. A. Foley, and G. P. Asner (2004), Land-use choices: Balancing human needs and ecosystem function, Front. Ecol. Environ, 2(5), 249-257.

Duran, A. (1985), Los Suelos del Uruguay, Hemisferio Sur, Montevideo. Dye, P. J. (1996), Climate, forest, and streamflow relationships in South African afforested catchments, Commonw. For. Rev., 75(1), 31-38.

Engel, V., E. G. Jobbágy, M. Stieglitz, M. Williams, and R. B. Jackson (2005), Hydrological consequences of Eucalyptus afforestation in the Argentine Pampas, Water Resour. Res., 41, W10409, doi:10.1029/ 2004WR003761.

Farley, K. A. (2007), Grasslands to tree plantations: Forest transition in the Andes of Ecuador, Ann. Assoc. Am. Geogr., 97(4), 755-771, doi:10.1111/j.1467-8306.2007.00581.x.

Farley, K. A., and E. F. Kelly (2004), Effects of afforestation of a páramo grassland on soil nutrient status, For. Ecol. Manage., 195, 281-290, doi:10.1016/j.foreco.2003.12.015.

Farley, K. A., E. F. Kelly, and R. G. M. Hofstede (2004), Soil organic carbon and water retention following conversion of grasslands to pine plantations in the Ecuadorian Andes, Ecosystems, 7(7), 729-739, doi:10.1007/s10021-004-0047-5.

Farley, K. A., E. G. Jobbágy, and R. B. Jackson (2005), Effects of afforestation on water yield: A global synthesis with implications for policy, Global Change Biol., 11(10), 1565-1576, doi:10.1111/j.13652486.2005.01011.x.

Foley, J. A., et al. (2005), Global consequences of land use, Science, 309(5734), 570-574, doi:10.1126/science.1111772.

Friberg, N., A. Rebsdorf, and S. E. Larsen (1998), Effects of afforestation on acidity and invertebrates in Danish streams and implications for freshwater communities in Denmark, Water Air Soil Pollut., 101, 235-256, doi:10.1023/A:1004949203686.

Giller, P. S., and J. O'Halloran (2004), Forestry and the aquatic environment: Studies in an Irish context, Hydrol. Earth Syst. Sci., 8(3), $314-326$.

Goodale, C. L., J. D. Aber, and W. H. McDowell (2000), The long-term effects of disturbance on organic and inorganic nitrogen export in the 
White Mountains, New Hampshire, Ecosystems, 3(5), 433-450, doi:10.1007/s100210000039.

Guo, L. B., and R. M. Gifford (2002), Soil carbon stocks and land use change: A meta analysis, Global Change Biol., 8(4), 345-360, doi:10.1046/j.1354-1013.2002.00486.x.

Harriman, R., and B. R. S. Morrison (1982), Ecology of streams draining forested and non-forested catchments in an area of central Scotland subject to acid precipitation, Hydrobiologia, 88(3), 251-263, doi:10.1007/ BF00008505.

Hesthagen, T., J. Heggenes, B. M. Larsen, H. M. Berger, and T. Forseth (1999), Effects of water chemistry and habitat on the density of young brown trout Salmo trutta in acidic streams, Water Air Soil Pollut., 112(1-2), 85-106, doi:10.1023/A:1005068404832.

Hood, E. W., M. W. Williams, and N. Caine (2003), Landscape controls on organic and inorganic nitrogen leaching across an alpine/subalpine ecotone, Green Lakes Valley, Colorado Front Range, Ecosystems, 6(1), 31 45, doi:10.1007/s10021-002-0175-8.

Howarth, R. W., et al. (1996), Regional nitrogen budgets and riverine $\mathrm{N}$ and $P$ fluxes for the drainages to the north Atlantic ocean: Natural and human influences, Biogeochemistry, 35, 75-139, doi:10.1007/BF02179825.

Huang, J., and E. P. Bachelard (1993), Effects of aluminium on growth and cation uptake in seedlings of Eucalyptus mannifera and Pinus radiata, Plant Soil, 149, 121-127, doi:10.1007/BF00010769.

Jackson, R. B., et al. (2000), Belowground consequences of vegetation change and their treatment in models, Ecol. Appl., 10(2), 470-483, doi:10.1890/1051-0761(2000)010[0470:BCOVCA]2.0.CO;2.

Jackson, R. B., S. R. Carpenter, C. N. Dahm, D. M. McKnight, R. J. Naiman, S. L. Postel, and S. W. Running (2001), Water in a changing world, Ecol. Appl., 11(4), 1027-1045, doi:10.1890/1051-0761(2001)011 [1027:WIACW]2.0.CO;2.

Jackson, R. B., E. G. Jobbágy, R. Avissar, S. B. Roy, D. Barrett, C. W. Cook, K. A. Farley, D. C. Le Maitre, B. A. McCarl, and B. C. Murray (2005), Trading water for carbon with biological carbon sequestration, Science, 310, 1944-1947, doi:10.1126/science.1119282.

Jenkins, A., B. J. Cosby, R. C. Ferrier, T. A. B. Walker, and J. D. Miller (1990), Modeling stream acidification in afforested catchments-An assessment of the relative effects of acid deposition and afforestation, J. Hydrol., 120(1-4), 163-181, doi:10.1016/0022-1694(90)90148-Q.

Jobbágy, E. G., and R. B. Jackson (2003), Patterns and mechanisms of soil acidification in the conversion of grasslands to forests, Biogeochemistry, 64, 205-229, doi:10.1023/A:1024985629259.

Jobbágy, E. G., and R. B. Jackson (2007), Groundwater and soil chemical changes under phreatophytic tree plantations, J. Geophys. Res., 112, G02013, doi:10.1029/2006JG000246.

Kelly-Quinn, M., D. Tierney, W. Roche, and J. J. Bracken (1996), Distribution and abundance of trout populations in moorland and afforested upland nursery streams in County Wicklow, Biol. Environ., 96(3), 127-139.

Lewis, W. M., J. M. Melack, W. H. McDowell, M. McClain, and J. E. Richey (1999), Nitrogen yields from undisturbed watersheds in the Americas, Biogeochemistry, 46, 149-162.

Marcar, N. E., and A. Termaat (1990), Effects of root-zone solutes on Eucalyptus camaldulensis and Eucalyptus bicostate seedlings: Responses to $\mathrm{Na}^{+}, \mathrm{Mg}^{2+}$, and $\mathrm{Cl}^{-}$, Plant Soil, 125(2), 245-254, doi:10.1007/ BF00010663.

Mark, A. F., and K. J. M. Dickinson (2008), Maximizing water yield with indigenous non-forest vegetation: A New Zealand perspective, Front. Ecol. Environ, 6(1), 25-34, doi:10.1890/060130.

McClurg, S. E., J. T. Petty, P. M. Mazik, and J. L. Clayton (2007), Stream ecosystem response to limestone treatment in acid impacted watersheds of the Allegheny Plateau, Ecol. Appl., 17(4), 1087-1104, doi:10.1890/ 06-0392.

Meynendonckx, J., G. Heuvelmans, B. Muys, and J. Feyen (2006), Effects of watershed and riparian zone characteristics on nutrient concentrations in the River Scheldt basin, Hydrol. Earth Syst. Sci., 10(6), 913-922.
Millennium Ecosystem Assessment (2005), Ecosystems and Human WellBeing: Synthesis, Island, Washington, D. C.

Ometo, J. P. H. B., L. A. Martinelli, M. V. Ballester, A. Gessner, A. V. Krusche, R. L. Victoria, and M. Williams (2000), Effects of land use on water chemistry and macroinvertebrates rates in two streams of the Piracicaba River basin, south-east Brazil, Freshwater Biol., 44(2), 327337, doi:10.1046/j.1365-2427.2000.00557.x.

Palmer, S. M., C. T. Driscoll, and C. E. Johnson (2004), Long-term trends in soil solution and stream water chemistry at the Hubbard Brook Experimental Forest: Relationship with landscape position, Biogeochemistry, 68, 51-70, doi:10.1023/B:BIOG.0000025741.88474.0d.

Paruelo, J. M., J. P. Guerschman, G. Piñeiro, E. G. Jobbágy, S. R. Verón, G. Baldi, and S. Baeza (2006), Cambios en el uso de la tierra en Argentina y Uruguay: Marcos conceptuales para su análisis, Agrociencia, 10(2), 47-61.

Perakis, S. S., and L. O. Hedin (2002), Nitrogen loss from unpolluted South American forests mainly via dissolved organic compounds, Nature, 415, 416-419, doi:10.1038/415416a.

Rhoades, C., and D. Binkley (1996), Factors influencing decline in soil pH in Hawaiian Eucalyptus and Albizia plantations, For. Ecol. Manage., 80, 47-56, doi:10.1016/0378-1127(95)03646-6.

Scanlon, B. R., I. Jolly, M. Sophocleous, and L. Zhang (2007), Global impacts of conversions from natural to agricultural ecosystems on water resources: Quantity versus quality, Water Resour. Res., 43, W03437, doi:10.1029/2006WR005486.

Schenk, H. J., and R. B. Jackson (2002), Rooting depths, lateral root spreads and below-ground/above-ground allometries of plants in waterlimited ecosystems, J. Ecol., 90, 480-494, doi:10.1046/j.1365-2745. 2002.00682.x.

Sobczak, W. V., S. Findlay, and S. Dye (2003), Relationships between DOC bioavailability and nitrate removal in an upland stream: An experimental approach, Biogeochemistry, 62, 309-327, doi:10.1023/ A:1021192631423.

Strauss, E. A., and G. A. Lamberti (2002), Effects of dissolved organic carbon quality on microbial decomposition and nitrification rates in stream sediments, Freshwater Biol., 47(1), 65-74, doi:10.1046/j.13652427.2002.00776.x.

van Dijk, A. I. J. M., and R. J. Keenan (2007), Planted forests and water in perspective, For. Ecol. Manage., 251, 1-9, doi:10.1016/j.foreco. 2007.06.010.

Vertessy, R. A. (1999), The impacts of forestry on streamflows: A review, paper presented at Second Forest Erosion Workshop, Coop. Res. Cent. for Catchment Hydrol., CSIRO Land and Water, Warburton, West. Aust., Australia.

Waters, D., and A. Jenkins (1992), Impacts of afforestation on water quality trends in two catchments in mid-Wales, Environ. Pollut., 77, 167-172, doi:10.1016/0269-7491(92)90073-J.

Zhang, L., W. R. Dawes, and G. R. Walker (2001), Response of mean annual evapotranspiration to vegetation changes at catchment scale, Water Resour. Res., 37(3), 701-708, doi:10.1029/2000WR900325.

K. A. Farley, Department of Geography, San Diego State University, San Diego, CA 92182-4493, USA. (kfarley@mail.sdsu.edu)

R. B. Jackson, E. G. Jobbágy, and G. Piñeiro, Department of Biology, Duke University, Durham, NC 27708, USA.

S. M. Palmer, School of Geography, University of Leeds, Leeds LS2 9JT, UK. 